\title{
Giant Cell Tumour Around Knee Managed by Curettage and Zoledronic Acid with Structural Support by Fibula Cortical Struts
}

\author{
Singaravadivelu V, PhD, Kavinkumar V, MS \\ Institute of Orthopaedics and Traumatology, Rajiv Gandhi Government General Hospital, Chennai, India

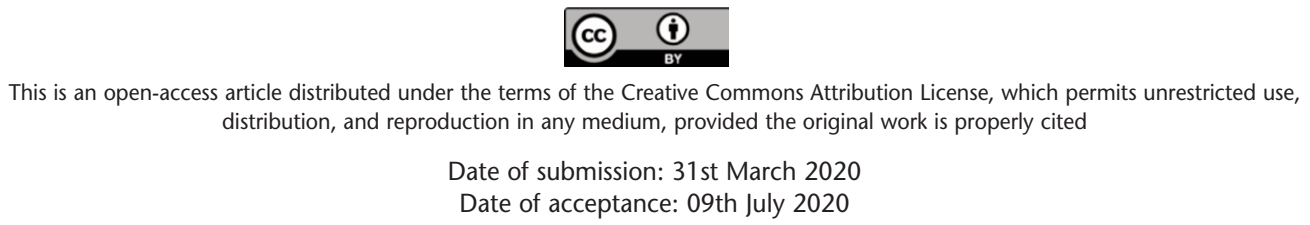

\begin{abstract}
Introduction: Giant cell tumour (GCT) of the bone is a benign tumour with a high tendency to recur after surgery. This study aimed to analyse prospectively the rate of local recurrence following management of giant cell tumours by curettage, using intravenous zoledronic acid as an adjuvant, and fibular struts to support the empty cavity after curettage. Materials and Methods: This study was carried out in ten cases of biopsy-proven GCTs: five males and five females, in the age group between 18 and 39 years. All patients were given three doses of zoledronic acid, one pre-operative and two post-operative. Extended curettage was done three weeks after the pre-operative dose of zoledronate. The cavity was left empty in all the cases. Fibular struts were used to support the cavity from collapse. Patients were followed-up for post-operative local recurrence. The functional status of the patients was assessed during each visit using the Musculoskeletal Tumour Society (MSTS) score.

Results: There were no recurrences at a follow-up of two years. All patients had a stable knee and were able to bear weight fully. The average knee flexion was $75^{\circ}$. The average MSTS score of the study was $92 \%$.

Conclusion: Extended curettage using hydrogen peroxide, systemic zoledronic acid adjuvant and leaving the cavity empty without using cancellous bone graft did not lead to a recurrence of GCT. Non-vascularised fibular strut provided adequate support while the cavity left empty after curettage did not collapse and there was good knee function.
\end{abstract}

Keywords:

GCT, zoledronic acid, fibula strut, recurrence

\section{INTRODUCTION}

Giant cell tumour is a common bone tumour accounting for $5 \%$ of all primary bone tumours. Although the mortality rate associated with the disease is low, the tumour is locally aggressive and has a high tendency to recur ${ }^{1}$. With the advancement in treatment options, the recurrence rate associated with GCT has fallen from an excess of $40 \%$ to less than $20 \%$ with extended curettage and use of adjuvants ${ }^{2-4}$.

The cavity left behind following the curettage is commonly filled with a bone graft or bone cement. Studies in literature ${ }^{5,6}$ had reported higher recurrence rates when iliac crest bone graft was used to fill the cavity. Bone cement is an inert material and does not get incorporated or remodelled along the lines of stress.

In this study, we postulated that leaving the cavity empty following curettage reduced the recurrence rates while the cavity did not collapse and the cortical struts used to support the empty cavity were incorporated with the host cortex.

\section{MATERIALS AND METHODS}

Ten consecutive cases of biopsy-proven GCT admitted in our unit between 2015 and 2017 were enrolled in the study. Primary GCT, recurrent GCT and GCT with pathological fractures were all included. Informed written consent was obtained from all the patients. MRI was done to confirm the intramedullary extent of the tumour and possible soft tissue extension. CT chest was done to rule out pulmonary metastasis. All the patients were available for a final followup. Ethical clearance was obtained from the Institutional Ethical Committee.

All the cases in our study were treated in the same manner. A creatinine clearance of $60 \mathrm{ml}$ per minute was taken as the minimum value for the administration of $4 \mathrm{mg}$ of zoledronic acid as per FDA standards. Zoledronic acid was administered in $100 \mathrm{ml}$ normal saline over 15 minutes after adequate fluid preloading.

Corresponding Author: Kavinkumar Vembanan, c/o Prof V Singaravadivelu, Institute of Orthopaedics and Traumatology, Rajiv Gandhi Government General Hospital, GH Post Office, 3, Poonamallee High Road, Near Chennai Central, near Park Town, Chennai, Tamil Nadu 600003, India Email: kavinkumarvembanan@gmail.com 
Extended curettage was done three weeks after the first dose of zoledronic acid. The surgery was performed under tourniquet control. The cavity was well visualised, and a curettage of the lesion was done. Power burrs were used to enhance surgical clearance. The cavity was thoroughly irrigated at the end of the procedure to wash away the tumour cells. The cavity was then treated with $3 \%$ hydrogen peroxide for three minutes. A total of three hydrogen peroxide washes were given.

The dimensions of the cavity were measured to calculate the length of fibula needed to be resected. Proximal tibia cavities were generally supported by two struts, one mediolateral and one superoinferior strut. Distal femur cavities were given an additional anteroposterior strut when the tumour involved a large portion of the posterior femoral condyle. The measured length of the fibula was resected using a posterolateral approach. The ipsilateral fibula was harvested in lesions involving the distal femur while the contralateral fibula was used in proximal tibia lesions. This protocol was followed to prevent further compromise in the stability of the leg when a fibular defect was made on the same side as the tibial cavity. The fibula was harvested sparing the proximal and distal $8 \mathrm{~cm}$.

The resected piece of fibula was split into multiple struts. The mediolateral strut was placed first. The superoinferior strut was positioned over the above strut and hitched against the cortex proximally or distally. This construct provided enough support to the cavity (Fig. 1). In one case, the fibular graft was secured to the host cortex using a $3.5 \mathrm{~mm}$ cortical screw (Fig. 2). The breadth of the graft was more than half the width of the tibial plateau to prevent point loading of the graft.

Patients were given above-knee casts in the immediate postoperative period. Three doses of antibiotics were given. Suture removal was done on the 12 th post-operative day. The patients were kept non-weight bearing with above-knee casts. The first follow-up visit was at three weeks postsurgery, during which the second dose of zoledronic acid was given. The final dose of zoledronic acid was given after another six weeks.

Routine radiographs were taken at six weeks, twelve weeks, three months, six months, one year; and at six-monthintervals thereafter. MRI was taken two years post-operative to detect recurrences. The decision to discontinue plaster immobilisation and commence knee mobilisation and weight-bearing was individualised for every patient depending on the consolidation of the graft. The patients were evaluated at six-month intervals using the Musculoskeletal Tumour Society (MSTS) score.

\section{RESULTS}

The average age of the patient in the study was 30 years (range 18 - 39 years). There were five men and five women (sex ratio - one: one). The distal femur (five) and proximal tibia (five) were equally involved in our study. Eight patients had a primary giant cell tumour while two patients had a recurrent giant cell tumour. The primary tumours were staged radiologically using the Campanacci grading. There were five cases of Grade II tumour and three cases of Grade III tumour. All patients were available for the final followup. The longest follow-up was 3.5 years, while the shortest follow-up was for 2.5 years. No recurrence was seen in any of the patients as confirmed with MRI scans two years after the surgery. Radiographs revealed good consolidation of the fibular struts and gradual filling up of the cavity. The joint space was maintained in all cases.

Patients were immobilised post-operatively in above-knee casts. The average period of immobilisation was 10 weeks (4 - 16 weeks). The patients were started on toe-touch weightbearing at the time of plaster removal. The average time taken to start full weight-bearing was 18 weeks (12 - 22 weeks). Four patients regained a knee flexion of more than $90^{\circ}$ while six patients had a knee flexion between $60^{\circ}$ and $90^{\circ}$. The mean MSTS score of our study was $92 \%$. Two patients had extensor hallucis longus (EHL) weakness on the side of fibular resection which eventually improved.

\section{DISCUSSION}

Ten cases were included in our study, as outlined in Table I. We had eight cases of the primary tumour and two cases of recurrent tumour. Of the two recurrent cases, the first case had a recurrence one year after curettage and cementation. The second case had a recurrence ten years after the first surgery, which was managed with curettage and cementation followed by a second recurrence two years later. The recurrent tumours were all operated primarily at other centres. The use of adjuvant therapy was not documented in both cases. A radical surgery like wide resection offered no significant additional disease control over extended curettage in the management of recurrent GCT. Steyern et al did not find any significant difference in recurrence rate while managing primary and recurrent tumours with extended curettage.

The presence of a pathological fracture was not a contraindication for inclusion in our study. Two patients in our series presented with a pathological fracture; one involving the distal femur (Fig. 3), and the other involving the proximal tibia. Intra-operatively, the tumour was found to be well contained within a pseudocapsule, and an intralesional curettage was done with resection of the pseudocapsule. Deheshi et $a l^{8}$ compared recurrence-free survival and functional outcome after curettage in patients 
Table I: Master chart summarising the findings of the study.

\begin{tabular}{|c|c|c|c|c|c|c|c|c|c|}
\hline $\begin{array}{l}\text { S. } \\
\text { No }\end{array}$ & $\begin{array}{l}\text { Agel } \\
\text { Sex }\end{array}$ & Diagnosis & $\begin{array}{l}\text { Campanacci } \\
\text { Grading }\end{array}$ & $\begin{array}{c}\text { Period of } \\
\text { immobilisation }\end{array}$ & $\begin{array}{l}\text { Time to } \\
\text { full weight } \\
\text { bearing }\end{array}$ & $\begin{array}{l}\text { Duration } \\
\text { of } \\
\text { follow-up }\end{array}$ & $\begin{array}{l}\text { Knee } \\
\text { flexion }\end{array}$ & $\begin{array}{c}\text { MSTS } \\
\text { Score at } \\
\text { final } \\
\text { follow-up }\end{array}$ & Complications \\
\hline 1. & $35 \mathrm{M}$ & $\begin{array}{c}\text { Primary GCT } \\
\text { proximal tibia - } \\
\text { left side }\end{array}$ & III & 16 weeks & 22 weeks & $\begin{array}{l}3 \text { years } \\
6 \text { months }\end{array}$ & $120^{\circ}$ & 29 & Nil \\
\hline 2. & $34 \mathrm{M}$ & $\begin{array}{l}\text { Primary GCT } \\
\text { distal femur - } \\
\text { left side }\end{array}$ & II & 16 weeks & 24 weeks & $\begin{array}{l}3 \text { years } \\
6 \text { months }\end{array}$ & $6^{\circ}$ & 26 & Nil \\
\hline 3. & $28 \mathrm{M}$ & $\begin{array}{l}\text { Primary GCT } \\
\text { distal femur - } \\
\text { Right side }\end{array}$ & III & 10 weeks & 16 weeks & $\begin{array}{l}3 \text { years } \\
3 \text { months }\end{array}$ & $75^{\circ}$ & 28 & Nil \\
\hline 4. & $34 \mathrm{~F}$ & $\begin{array}{c}\text { Primary GCT } \\
\text { distal femur with } \\
\text { pathological } \\
\text { fracture- } \\
\text { Right side }\end{array}$ & III & 14 weeks & 20 weeks & 3 years & $60^{\circ}$ & 27 & Nil \\
\hline 5. & $28 \mathrm{~F}$ & $\begin{array}{c}\text { Primary GCT } \\
\text { proximal tibia } \\
\text { with pathological } \\
\text { fracture - } \\
\text { Right side }\end{array}$ & II & 10 weeks & 18 weeks & 3 years & $60^{\circ}$ & 26 & Nil \\
\hline 6. & $18 \mathrm{~F}$ & $\begin{array}{l}\text { Primary GCT } \\
\text { proximal tibia - } \\
\text { Right side }\end{array}$ & II & 10 weeks & 16 weeks & 3 years & $120^{\circ}$ & 29 & Nil \\
\hline 7. & $38 \mathrm{M}$ & $\begin{array}{l}\text { Recurrent GCT } \\
\text { proximal tibia - } \\
\text { Right side }\end{array}$ & - & 4 weeks & 12 weeks & $\begin{array}{l}2 \text { years } \\
10 \text { months }\end{array}$ & $75^{\circ}$ & 27 & Nil \\
\hline 8. & $23 \mathrm{~F}$ & $\begin{array}{l}\text { Recurrent GCT } \\
\text { proximal tibia - } \\
\text { Right side }\end{array}$ & - & 6 weeks & 18 weeks & $\begin{array}{l}2 \text { years } \\
9 \text { months }\end{array}$ & $110^{\circ}$ & 29 & EHL Weakness \\
\hline 9. & $39 \mathrm{M}$ & $\begin{array}{l}\text { Primary GCT } \\
\text { distal femur - } \\
\text { Right side }\end{array}$ & II & 8 weeks & 14 weeks & $\begin{array}{l}2 \text { years } \\
6 \text { months }\end{array}$ & $75^{\circ}$ & 27 & EHL Weakness \\
\hline 10. & $23 \mathrm{~F}$ & $\begin{array}{l}\text { Primary GCT } \\
\text { distal femur - } \\
\text { Left side }\end{array}$ & II & 8 weeks & 18 weeks & $\begin{array}{l}2 \text { years } \\
6 \text { months }\end{array}$ & $100^{\circ}$ & 28 & Nil \\
\hline
\end{tabular}
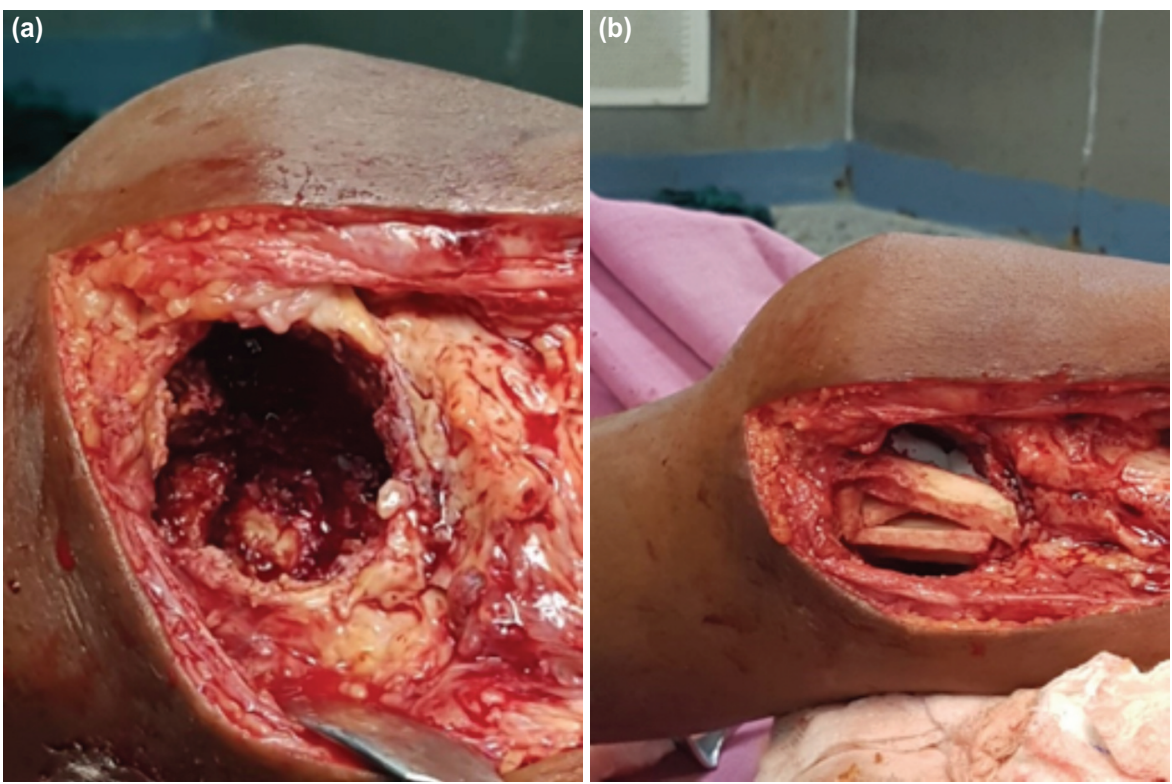

Fig. 1: (a) Cavity after curettage (b) Cavity supported with fibula cortical struts. 

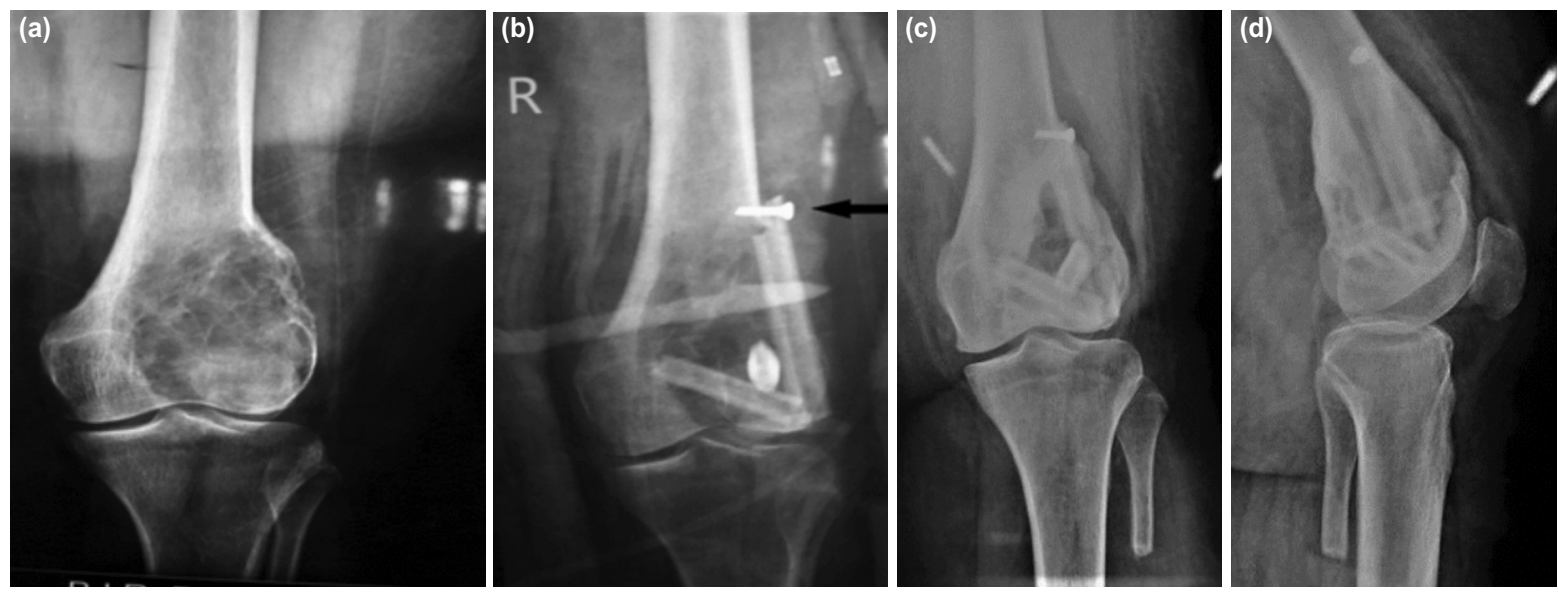

Fig. 2: (a) Giant cell tumour involving the lateral femoral condyle in 24-year-old. (b) Cavity was supported with three struts after curettage. Arrow indicates a $3.5 \mathrm{~mm}$ cortical screw used to secure the superoinferior strut to the lateral femoral cortex. (c,d) Good consolidation of the graft at two years post-operation.
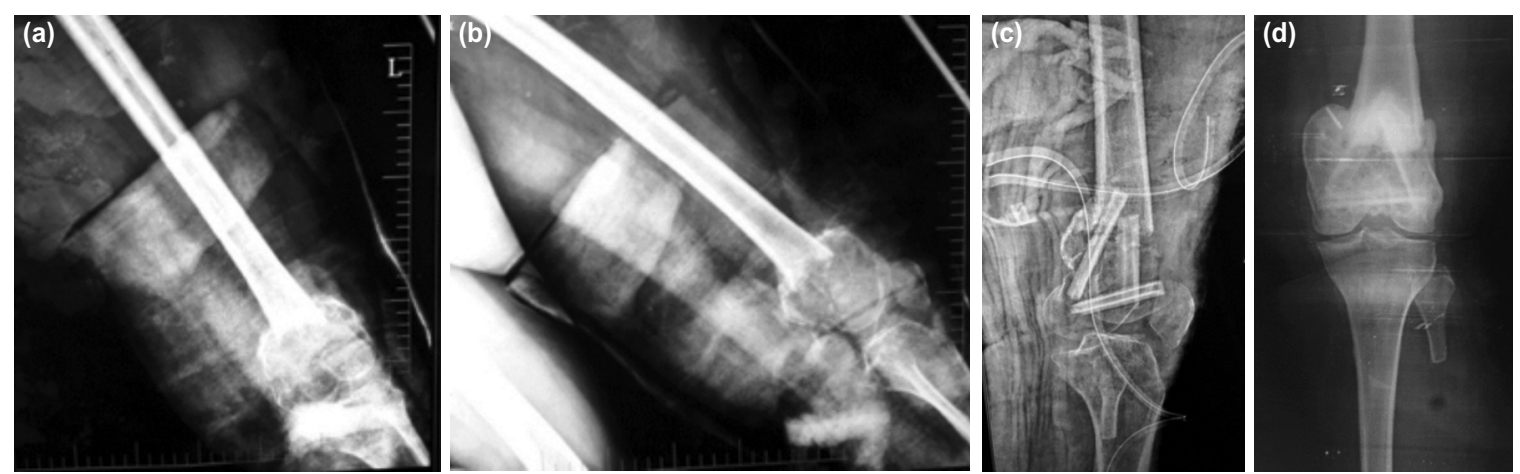

Fig. 3: (a,b) Giant cell tumour of distal femur presenting with a pathological fracture. (c) Immediate post-operative radiograph. (d) Two years post-operative radiograph.
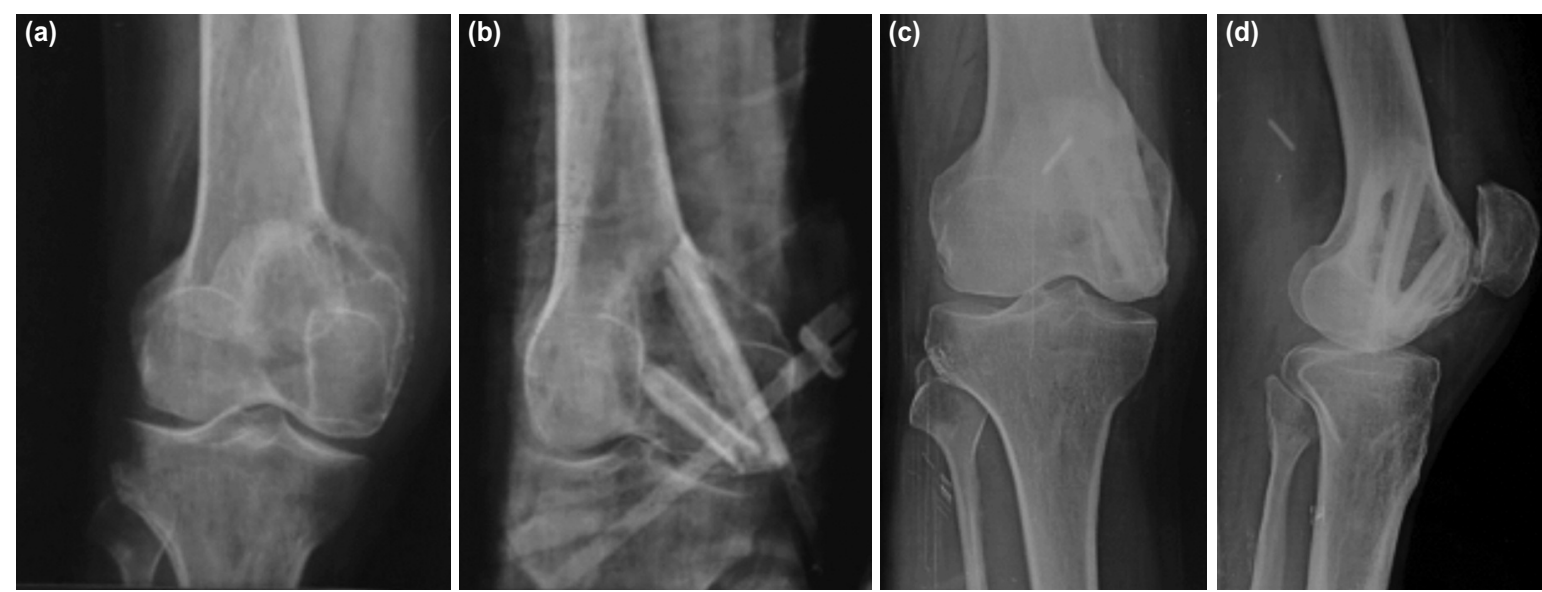

Fig. 4: (a) Giant cell tumour of the medial femoral condyle in a 38-year-old. (b) Immediate post-operation radiograph shows cavity supported with two struts. $(c, d)$ Good hypertrophy and incorporation of the graft at two years post-operation. 
with and without pathologic fracture, with the outcomes being comparable.

Intralesional curettage has emerged as the preferred mode of treatment in GCT, considering the benign nature of the disease and the longer life expectancy of the affected individuals compared to other bone tumours. Systemic adjuvants have supplemented the curettage technique by controlling the micrometastasis. Two commonly used agents included zoledronic acid and denosumab. Zoledronic acid, a third-generation bisphosphonate, acted by promoting the apoptosis of stromal cells, the main neoplastic component in GCT $^{9}$. Several studies had reported low recurrence rates while using zoledronic acid ${ }^{10-14}$.

Tse et $a l^{10}$ had a recurrence rate of $4 \%$ (1 in 24) when zoledronic acid was used as an adjuvant compared to $30 \%$ in the group treated without zoledronic acid (6 of 20). The surgical procedure was individualised for each case and varied from curettage with cementation or bone grafting to wide resection. The mean time to recurrence in the control group was 12 months. Gouin et al ${ }^{11}$ performed curettage of GCT in 24 patients, using no local adjuvant and filled the cavity with bone cement supplemented with internal fixation. The curettage was supplemented with five doses of post-operative zoledronic acid. There were two recurrences at the end of two years with a third recurrence at the end of five years giving a total recurrence rate of $15 \%$. Yu et $a l^{12}$ managed 16 cases of GCT of the distal femur with intralesional curettage and cementation supplemented with post-operative oral alendronate. No recurrence was noted at the end of two years. Kundu et $a l^{13}$ treated 18 cases of GCT with three doses of zoledronic acid pre-operatively. Extended curettage was done two weeks after the last dose, and the cavity was filled with bone graft to eliminate the possible confounding effect of bone cement. They had only one recurrence in the study group (5\%) as against four recurrences in the control group (21\%). In our series of 10 cases of GCT followed-up for a minimum period of two years, there were no recurrences as confirmed using MRI scans (minimum: 2.5 years; maximum: 3.5 years).

The number and duration of zoledronic acid administered varied in the reported studies. We administered three doses of zoledronic acid at an interval of six weeks. The first dose was given pre-operatively, and two more doses were given after surgery to supplement our extended curettage with hydrogen peroxide. The time interval between administration of the pre-operative dose of zoledronic acid and surgery was 21 days. Nishisho et al ${ }^{14}$ advocated a three week waiting period between zoledronic acid and surgery based on in vivo and in vitro studies. Six patients experienced a mild fever within 48 hours of administering zoledronic acid. This is the only notable reaction to the administration of zoledronate. The rise in temperature was benign and settled with antipyretics.
The resected specimens were sent for histopathological examination. The percentage of necrosis of the giant cells in the resected specimens was documented. Pre-operative administration of zoledronic acid had produced more than $50 \%$ necrosis in the resected specimens compared to the biopsy tissue. This was consistent with the observations of Cheng et al who had a stromal cell necrosis of 54\% and giant cell necrosis of $74 \%$ while using zoledronic acid 9 .

With the advent of denosumab, promising results had been shown in the management of inoperable or metastatic GCT. However, its superiority over zoledronic acid in conventional limb GCT had not been established ${ }^{15}$. High costs and long duration of treatment before surgery made it less costeffective. Denosumab promoted new bone formation at the periphery of the tumour, which made the differentiation between normal and pathological tissue difficult during curettage. Neoplastic cells might be left behind the newly formed bone ${ }^{15}$. Denosumab had been associated with a higher incidence of grade 3-4 adverse reactions like osteonecrosis of jaw, hypocalcaemia, anaemia and $\operatorname{arthralgia}^{16}$.

The cavity was not filled in our procedure. Bone cavities left behind the following curettage were filled up with blood, which clotted and eventually ossified to form mature bone. Prosser et al reported on 166 cases of GCT left empty after curettage, which gradually filled up with new bone that consolidated with time ${ }^{17}$. Iliac crest bone graft was not used to fill the cavity in any patient due to the postulated increase in recurrence reported by several studies when the cavity was filled with bone graft. Gouin $e t a l^{5}$ ascribed an odd's ratio of 3.9 for recurrence of the tumour when the cavity was filled with cancellous bone graft. Gao et al had a threefold increase in recurrence when the bone graft was used compared to bone cement ${ }^{6}$.

Immediate weight bearing could be started when bone cement was used to fill the cavity. Although bone cement allowed for early rehabilitation, it was a biologically inert material and did not remodel along the lines of stress. Another possible complication while using bone cement was the risk of articular cartilage damage on account of variation in modulus of elasticity between bone cement and articular cartilage and the heat generated during cementation ${ }^{18}$. The heat liberated also resulted in a radiolucent zone at the bone cement interface, which could lead on to micromotions between bone and cement resulting in fractures ${ }^{19}$. The sandwich technique was introduced to overcome this potential problem by packing a layer of iliac crest bone graft between the subchondral bone and bone cement. However, this technique introduced bone graft into the cavity, which could enhance the risk of recurrence.

The fibula strut grafts could serve the role of bone cement at the cost of a slight delay in weight-bearing while avoiding 
the possible joint destruction. These struts had the added advantage of incorporating with the host cortex and remodelling along the lines of stress. The anteroposterior and mediolateral struts were strategically placed over the condyles to ensure coverage over at least two-thirds of the subchondral surface area. Intra-operative varus-valgus stress testing was done to ensure no movement of the graft and collapse of the cavity. Post-operatively patients were immobilised with above-knee slabs till there was adequate new bone formation. By three months, all the cavities showed good consolidation of the graft with adequate support to the subchondral bone. Hypertrophy and incorporation of the fibular graft were noted in all the cases. Krieg et al used non-vascularised fibular grafts to bridge 30 cases of tumour cavity post-resection. They concluded that non-vascularised fibular grafts also showed biological activity, evident by their hypertrophy and fracture healing potential through the formation of callus ${ }^{20}$.

Two patients had post-operative extensor hallucis longus weakness on the side of fibular resection. EHL weakness had commonly been reported in literature following resection of long segments of the fibula. Verma et $a l^{21}$ reported EHL weakness in 43 out of 85 cases of fibular resection (50\%). Singhade et $a l^{22}$ had 10 cases $(38 \%)$ of EHL weakness following fibular resection. Consistent with the observations of other authors, the weakness was partial and completely recovered within six months in both cases. The distal eight $\mathrm{cm}$ of the fibula was preserved to ensure ankle stability. Similarly, the proximal third of the fibula was left intact to protect the common peroneal nerve and knee stability. None of our patients had any functional limitations due to pain over donor site or sensory disturbance.

The average time taken to commence knee mobilisation was 10.2 weeks. The patients were advised to do isometric quadriceps strengthening exercises during this period. The patients were then started on physiotherapy, emphasising on quadriceps strengthening and knee flexion. The prolonged period of knee immobilisation did not affect the postoperative knee range of movement significantly to deter normal activities. Four patients were able to achieve a knee flexion beyond $90^{\circ}$ while the other six patients achieved between $60^{\circ}$ and $90^{\circ}$ of knee flexion.
The average time taken for the patients to fully weight bear without support was 18 weeks (12 - 24 weeks). All the patients were able to resume their pre-surgery work function. Consolidation of the graft was achieved in all the cases. (Fig. 4) The knee was stable, and the alignment achieved intraoperatively was maintained until the final follow-up. The wafer-thin subchondral bone supported only with fibula struts did not collapse, and there was no radiographic evidence of arthritis at the final follow-up.

The mean MSTS score of our series was $92 \%$ which is comparable to the results obtained by other surgeons using other modes of treatment. Saibaba et $a l^{23}$ had an MSTS score of $92 \%$ in their series of 36 patients managed with curettage and reconstruction using the sandwich technique. Gao et al ${ }^{6}$ had a mean MSTS score of $94.7 \%$ in 31 patients managed with curettage and cementation. The major limitations of the study included a short follow-up period, a small sample size and lack of a control group.

\section{CONCLUSION}

Several methods have been tried by surgeons to decrease the recurrence of GCT. We believed that by not adding cancellous bone graft to the cavity after curettage, with local adjuvant hydrogen peroxide and systemic zoledronic acid to supplement the curettage with power burrs, would decrease the recurrence rates in GCT. Fibula struts provided adequate mechanical stability to the empty cavity. We had no recurrence in any of the cases over a follow-up period of more than two years.

\section{CONFLICT OF INTEREST}

The authors declare no potential conflicts of interest. 


\section{REFERENCES}

1. Campanacci M, Baldini N, Boriani S, Sudanese A. Giant-cell tumor of bone. J Bone Joint Surg Am. 1987; 69(1): 106-14.

2. Turcotte RE. Giant cell tumour of bone. Orthop Clin North Am. 2006; 37: 35-51. doi: 10.1016/j.ocl.2005.08.005

3. Saiz P, Virkus W, Piasecki P, Templeton A, Shott A, Gitelis S. Results of Giant cell tumours treated with intralesional excision. Clin Orthop Relat Res. 2004; (424): 221-6. doi: 10.1097/01.blo.0000128280.59965.e3

4. Capanna R, Sudanese A, Baldini N, Campanacci M. Phenol as an adjuvant in the control of local recurrence of benign neoplasm of bone treated by curettage. Ital J Orthop Traumatol. 1985; 11(3): 381-8.

5. Gouin F, Dumaine V, French Sarcoma Group. Local recurrence after curettage treatment of giant cell tumors in peripheral bones: retrospective study by the GSF-GETO (French Sarcoma and Bone Tumor Study Group). Orthop Traumatol Surg Res. 2013; 99(6 Suppl): S313-318. doi: 10.1016/j.otsr.2013.07.006

6. Gao ZH, Yin JQ, Xie XB, Zou CY, Huang G, Wang J, et al. Local control of giant cell tumors of the long bone after aggressive curettage with and without bone cement. BMC Musculoskeletal Disord. 2014; 15: 330. doi: 10.1186/1471-2474-15-330

7. Steyern FV, Bauer HC, Trovik C, Kivioja A, Bergh P, Jorgensen PH. Treatment of local recurrences of GCT in long bones after curettage and cementing. A scandinavian sarcoma group study. J Bone Joint Surg Br. 2006; 88: 1656-8. doi: 10.1302/0301620X.88B4.17407

8. Deheshi BM, Jaffer SN, Griffin AM, Ferguson PC, Bell RS, Wunder JS. Joint salvage for pathologic fracture of giant cell tumor of the lower extremity. Clin Orthop Relat Res. 2007; 459: 96-104. doi: 10.1097/BLO.0b013e31805d85e4

9. Cheng YY, Huang L, Lee KM, Xu JK, Zheng MH, Kumta SM. Bisphosphonates induce apoptosis of stromal tumour cells in giant cell tumour of Bone. Calcif Tissue Int. 2004; 75: 71-7. doi: 10.1007/s00223-004-0120-2

10. Tse LF, Wong KC, Kumta SM, Huang L, Chow TC, Griffith JF. Bisphosphonates reduce local recurrence in extremity giant cell tumor of bone: a case-control study. Bone. 2007; 42: 68-73. doi: 10.1016/j.bone.2007.08.038

11. Gouin F, Rochwerger AR, Di Marco A, Rosset P, Bonnevialle P, Fiorenza F, et al. Adjuvant treatment with zoledronic acid after extensive curettage for giant cell tumours of bone. Eur J Cancer. 2014; 50: 2425-31. doi: 10.1016/j.ejca.2014.06.003

12. Yu X, Xu M, Xu S, Su Q. Clinical outcomes of giant cell tumor of bone treated with bone cement filling and internal fixation, and oral bisphosphonates. Oncol Lett. 2013; 5: 447-51. doi: 10.3892/ol.2012.1036

13. Kundu ZS, Sen R, Dhiman A, Sharma P, Siwach R, Rana P. Effect of intravenous Zoledronic acid on histopathology and recurrence after extended curettage in giant cell tumors of bone: A comparative prospective study. Indian J Orthop. 2018; 52(1): 45-50. doi: 10.4103/ortho.IJOrtho_216_17

14. Nishisho T, Hanaoka N, Miyagi R, Sakai T, Toki S, Takahashi M, et al. Local administration of zoledronic acid for giant cell tumor of bone. Orthopedics. 2015; 38(1): e25-30. doi: 10.3928/01477447-20150105-56

15. Gaston CL, Grimer RJ, Parry M, Stacchiotti S, Dei Tos AP, Gelderblom H, et al. Current status and unanswered questions on the use of Denosumab in giant cell tumor of bone. Clin Sarcoma Res. 2016; 6(1): 15. doi: 10.1186/s13569-016-0056-0

16. Chawla S, Henshaw R, Seeger L, Choy E, Blay JY, Ferrari S, et al. Safety and efficacy of Denosumab for adults and skeletally mature adolescents with giant cell tumor of bone: interim analysis of open-label parallel-group, phase 2 study. Lancet Oncol. 2013; 14(9): 901-8. doi: 10.1016/S1470-2045(13)70277-8

17. Prosser GH, Baloch KG, Tillman RM, Carter SR, Grimer RJ. Does curettage without adjuvant therapy provide low recurrence rates in giant cell tumors of bone? Clin Ortho Relat Res. 2005; 435: 211-8. doi: 10.1097/01.blo.0000160024.06739.ff

18. Bini SA, Gill K, Johnston JO. Giant cell tumor of bone. Curettage and cement Reconstruction. Clin Orthop Relat Res. 1995; (321): 245-50.

19. Radev BR, Kase JA, Askew MJ, Weiner SD. Potential for thermal damage to articular cartilage by PMMA reconstruction of a bone cavity following tumor excision: A finite element study. J Biomech. 2009; 42: 1120-6. doi: 10.1016/j.jbiomech.2009.02.005

20. Krieg AH, Hefti F. Reconstruction with non-vascularised fibular grafts after resection of bone tumours. J Bone Joint Surg Br. 2007; 89(2): 215-21. doi: 10.1302/0301-620X.89B2.17686

21. Verma AK, Kushwaha NS, Saini A, Waliullah S, Navadaya MK, Kumar D. Retrospective analysis of donor site morbidity following partial fibular resection. Int J Contemp Med Res. 2016; 3: 1571-4. 
22. Shingade VU, Jagtap SM, Ranade AB. Weakness of extensor hallucis longus after removal of non-vascularised fibula as an autograft. J Bone Joint Surg Br. 2004; 86(3): 384-7. doi: 10.1302/0301-620x.86b3.14748

23. Saibaba B, Chouhan DK, Kumar V, Dhillon MS, Rajoli SR. Curettage and reconstruction by the sandwich technique for giant cell tumours around the knee. J Orthop Surg. 2014; 22: 351-5. doi: 10.1177/230949901402200317 